\section{Anti-apoptotic Mcl-1 is essential for the development and sustained growth of acute myeloid leukemia}

\author{
Stefan P. Glaser, ${ }^{1,2}$ Erinna F. Lee, ${ }^{1,2}$ \\ Evelyn Trounson, ${ }^{1}$ Philippe Bouillet, ${ }^{1,2}$ \\ Andrew Wei, ${ }^{3}$ W. Douglas Fairlie, ${ }^{1,2}$ David J. Izon, ${ }^{4}$ \\ Johannes Zuber, ${ }^{5,6}$ Amy R. Rappaport, ${ }^{5,7}$ \\ Marco J. Herold, ${ }^{1,2}$ Warren S. Alexander, ${ }^{1,2}$ \\ Scott W. Lowe, ${ }^{5,7,8}$ Lorraine Robb, ${ }^{1,2}$ \\ and Andreas Strasser ${ }^{1,2,9}$
}

\begin{abstract}
${ }^{1}$ The Walter and Eliza Hall Institute, Parkville, Melbourne, Victoria 3052, Australia; ${ }^{2}$ Department of Medical Biology, The University of Melbourne, Parkville, Melbourne, Victoria 3010, Australia; ${ }^{3}$ The Australian Centre for Blood Diseases, Alfred Hospital and Monash University, Melbourne, Victoria 3004, Australia; ${ }^{4}$ St. Vincent's Institute, Fitzroy, Victoria 3065, Australia; ${ }^{5}$ Cold Spring Harbor Laboratories, Cold Spring Harbor, New York 11724, USA; ${ }^{6}$ Research Institute of Molecular Pathology (IMP), A-1030 Vienna, Austria; ${ }^{7}$ Watson School of Biological Sciences, Cold Spring Harbor, New York 11724, USA; ${ }^{8}$ Memorial Sloan-Kettering Cancer Center, New York, New York 10065, USA
\end{abstract}

Acute myeloid leukemia (AML) frequently relapses after initial treatment. Drug resistance in AML has been attributed to high levels of the anti-apoptotic Bcl-2 family members Bcl- $x_{L}$ and Mcl-1. Here we report that removal of Mcl-1, but not loss or pharmacological blockade of Bcl- $x_{L}, B c l-2$, or Bcl-w, caused the death of transformed AML and could cure disease in AML-afflicted mice. Enforced expression of selective inhibitors of prosurvival Bcl-2 family members revealed that Mcl-1 is critical for survival of human AML cells. Thus, targeting of Mcl-1 or regulators of its expression may be a useful strategy for the treatment of AML.

Supplemental material is available for this article.

Received November 9, 2011; revised version accepted December 14, 2011.

Acute myeloid leukemia (AML) is a heterogeneous disease, with treatment outcome after intensive chemotherapy strongly influenced by cytogenetic and molecular characteristics of the cancer. Several recurrent AML oncogenic fusion lesions have been linked to a high risk of relapse after chemotherapy, including chromosomal translocations involving the Mll (mixed-lineage leukemia) gene (MLL-ENL and MLL-AF9, particularly found in infants or individuals that had previously been treated

[Keywords: acute myeloid leukemia; apoptosis; Mcl-1; Bcl- $\mathrm{x}_{\mathrm{L}}$ ] ${ }^{9}$ Corresponding author.

E-mail strasser@wehi.edu.au.

Article is online at http://www.genesdev.org/cgi/doi/10.1101/gad.182980.111. with topoisomerase inhibitors) (Ayton et al. 2004) or Aml1 gene (AML1-ETO9, found in $\sim 15 \%$ of human AML cases) (Yan et al. 2006; Jiao et al. 2009). Mice transplanted with bone marrow-derived hematopoietic stem/progenitor cells that had been retrovirally transduced with the AML1-ETO9a (Yan et al. 2006) oncogene succumb to myeloblastic AML highly reminiscent of the human disease induced by the same oncogenic lesion. Similar transduction/transplantation models for expression of MLL-ENL (Lavau et al. 2000), MLL-AF9 (Somervaille and Cleary 2006), Mixl1 (Glaser et al. 2006), or Hoxa9 (Thorsteinsdottir et al. 2002) oncogenes cause monocytic and myelomonocytic AML in mice, recapitulating the human subtypes of AML often associated with these oncogenes. Like human AML (Estey and Dohner 2006), these murine leukemias often respond only transiently to anti-cancer therapeutics, with relapse of drug refractory disease in a significant proportion (Zuber et al. 2009). Anticancer therapy kills many tumor cells (at least in part) through induction of apoptosis, and defects in the programmed cell death machinery are frequently associated with poor response (Kaufmann et al. 1998; Johnstone et al. 2002). Recent studies have identified somatic amplification of the genomic regions containing the antiapoptotic genes mcl-1 or bcl-x (Beroukhim et al. 2010) or post-translational stabilization of Mcl-1 protein (Schwickart et al. 2010) in diverse human cancers. We used mouse as well as human AMLs to determine which anti-apoptotic Bcl-2 family members are essential for development and sustained growth of this hematological malignancy to gain insight into which of these proteins should be targeted for therapeutic benefit.

\section{Results and Discussion}

\section{Deletion of mcl-1 but not bcl-x kills transformed myeloid cells in culture}

We employed gene targeted mice expressing a tamoxifenregulated Cre recombinase estrogen receptor fusion protein (Rosa26-Cre-ERT2 mice, hereafter called Cre) (Seibler et al. 2003) to allow controlled inactivation of loxP targeted (floxed, hereafter denoted fl) bcl-x (Wagner et al. 2000) or mcl-1 (Vikstrom et al. 2010) alleles (Supplemental Fig. 1A). We used cells of six different genotypes for analysis: wild-type (wt) to reveal toxic effects of tamoxifen, $\mathrm{cre} /+$ heterozygotes to detect toxicity of the activated Cre recombinase, and cre/+ cells that are either heterozygous $(f l /+)$ or homozygous $(f 1 / f l)$ for conditional bcl-x or $m c l-1$ alleles to examine the consequences of loss of the corresponding anti-apoptotic proteins (Bcl- $\mathrm{x}_{\mathrm{L}}$ and $\left.\mathrm{Mcl}-1\right)$. Bone marrow-derived hematopoietic stem/progenitor cells were infected with retroviruses encoding MLL-ENL, MLL-AF9, AML1-ETO9a, Mixl1, or Hoxa9 plus GFP (from an IRES) as a marker (Supplemental Fig. 1B). Each transduced cell population readily yielded immortalized cell lines exhibiting an immature myeloid profile, with the exception of AML1-ETO9a transduced cells, which exhibited a more differentiated morphology (Supplemental Fig. 1C). Treatment with tamoxifen resulted within $24 \mathrm{~h}$ in near complete recombination of both conditional $b c l-x^{f l}$ or $m c l-1^{f l}$ alleles (Supplemental Fig. 1D). Moreover, this treatment caused nearly complete loss of $\mathrm{Bcl}-\mathrm{x}_{\mathrm{L}}$ protein 
in $b c l-x^{f l / f l} ; c r e /+$ cells and almost complete loss of Mcl-1 (and increase of Bim but not tBid or Puma) protein in $\mathrm{mcl}$ $1^{f l / f 1}$;cre/+ cells (Supplemental Fig. 1E). Tamoxifen exerted no toxicity on wild-type cells, but Cre activation reduced the viability of cre/+ cells to $\sim 70 \%$ compared with untreated cultures (Fig. 1A; Supplemental Fig. 1F). Bcl- $\mathrm{X}^{f l /+} ; \mathrm{cre} /+$ and $b c l-x^{f l / f 1} ; c r e /+$ cells showed slightly increased death compared with the cre/+ cells, displaying an initial drop in viability to $57 \%-74 \%$ or $45 \%-57 \%$, respectively (Fig. 1A; Supplemental Fig. 1F). Addition of tamoxifen reduced the viability of $\mathrm{mcl}-1^{f l / t}$; cre/+ cells to $37 \%-55 \%$ and, remarkably, completely killed all $m c l-1^{f l / f 1} ; \mathrm{cre} /+$ lines (Fig. 1A). These results show that Mcl-1 but not Bcl- $\mathrm{x}_{\mathrm{L}}$ is essential for sustained survival of transformed myeloid cells in vitro.

We next examined the mechanism by which these transformed cells are killed upon mcl-1 gene deletion. Overexpression of Bcl-2, Bcl- $\mathrm{x}_{\mathrm{L}}$, or Mcl-1 (Supplemental Fig. 1G) prevented this cell death (Fig. 1B). Among the apoptosis initiators tested, Bim was the most highly expressed in these cells, and, remarkably, knockdown of this BH3-only protein by shRNA (Supplemental Fig. 1H) prevented apoptosis of MLL-ENL transformed cells undergoing mcl-1 deletion (Fig. 1B). These results demonstrate that Mcl-1 deletion kills transformed myeloid cells in vitro by activating the "Bcl-2-regulated" (also called "mitochondrial," "intrinsic," or "stress") apoptotic pathway in a Bim-dependent manner (Youle and Strasser 2008).

\section{Murine AML are more sensitive to Mcl-1 deletion than nontransformed stem cells and myeloid progenitors}

We next generated AML in vivo by reconstituting lethally irradiated mice with MLL-ENL or MLL-AF9 retrovirus-

infected bone marrow-derived hematopoietic stem/progenitor cells. We used the Cre/loxP system to induce loss of Bcl- $\mathrm{x}_{\mathrm{L}}$ or Mcl-1 (Supplemental Fig. 2A), or tetracyclineregulated RNAi (Zuber et al. 2011a) for knockdown of Mcl-1 (Supplemental Fig. 2B). All recipient mice developed AML within $5 \mathrm{wk}$ after reconstitution (Supplemental Fig. 2C,D). Knockdown of Mcl-1 by RNAi caused apoptosis and rapid depletion of $\left(\mathrm{dsRed}^{+} / \mathrm{Venus}^{+}\right)$mcl-1 shRNAexpressing AML cells that had been transformed by combined expression of the MLL-AF9 and N-ras oncogenes (Fig. 1C). In agreement with the data described above (Fig. 1B), this death could be inhibited by overexpression of Bcl-2 or Mcl-1 (Fig. 1C).

For Mcl-1 inhibition to become a feasible strategy for AML therapy, there needs to be a "therapeutic window" in which leukemic cells are more sensitive than normal hematopoietic stem cells (which require Mcl-1 for survival) (Opferman et al. 2005). Treatment with tamoxifen caused efficient recombination of $\mathrm{mcl}-1^{f l}$ alleles in FACSsorted nontransformed LSK (lineage marker ${ }^{-} \mathrm{Sca}-1^{+} \mathrm{c}-\mathrm{Kit}^{+}$) stem and myeloid progenitors from $\mathrm{mcl}^{-1}{ }^{\mathrm{fl} /+} ; \mathrm{cre} /+$ or $\mathrm{mcl}-$ $1^{f l / f 1} ; \mathrm{cre} /+$ mice, as demonstrated by flow-cytometric detection of the hCD4 reporter (Supplemental Fig. 3A). Mcl-1 deletion lowered the viability of $m c l-1^{f l /+} ;$ cre/+ LSK cells to $80 \%$ and that of $m c l-1^{f l / f l} ; \mathrm{cre} /+$ LSK cells to $34 \%$, compared with untreated cells (Fig. 2A). Myeloid progenitors were slightly more susceptible to Mcl-1 deletion, showing viability of $91 \%$ for cre $/+, 66 \%$ for $\mathrm{mcl}^{-1}{ }^{f l /+} ; \mathrm{cre} /+$, and $15 \%$ for $m c l-1^{f l / f 1} ; \mathrm{cre} /+$ cells (Fig. 2A). When MLL-ENL and MLL-AF9 transformed AML cells were treated in vitro with tamoxifen for $48 \mathrm{~h}$, no effect was observed in wildtype cells, whereas the viability of $c r e /+$ cells dropped to $\sim 65 \%$ (Fig. 2B). The $b c l-x^{f l /+} ;$ cre $/+$ and $b c l-x^{f l / f l} ;$ cre $/+$ leukemic cells displayed a reduction in viability that was slightly higher compared with that of cre/+ cells (Fig. 2B). In contrast, the viability of $\mathrm{mcl}^{-1} 1^{\mathrm{fl} /+}$;cre/+ cells dropped to $\sim 35 \%$, and most $m c l-1^{f l / f 1} ;$ cre $/+$ cells were killed within $72 \mathrm{~h}$ (Fig. 2B). These results demonstrate that while Mcl-1 is important in both normal stem/myeloid progenitor cells and AML cells, the AML cells were significantly more susceptible to loss of Mcl-1, even when they were cocultured (Supplemental Fig. 3B). Thus, it might be possible to establish a "therapeutic window" for Mcl-1 inhibitors in AML therapy.

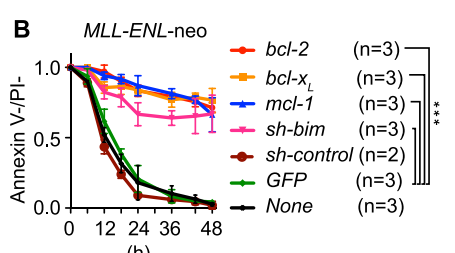

(h)

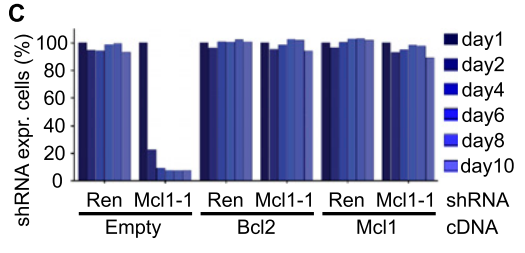

Figure 1. Impact of conditional deletion of $b c l-x$ or $m c l-1$ in transformed myeloid and AML cells in vitro. $(A)$ Cells of the indicated genotypes, transformed with the oncogenes indicated, were grown for $72 \mathrm{~h}$ in medium with or without tamoxifen. Viable $\left(\right.$ Annexin $\left.V^{-} / \mathrm{PI}^{-}\right)$cells were enumerated by flow cytometry. Graphs represent the means \pm SEM of the ratio of viable tamoxifen-treated cells versus viable untreated cells $(n=3-5$ independently transduced and sorted cell lines for each transforming oncogene and genotype). (B) $M L L$-ENL/neo transformed $m c l-1^{f l / f l} ;$ creER/+ cells were secondarily transduced with retroviruses encoding GFP alone or GFP plus Bcl-2, Bcl- $\mathrm{x}_{\mathrm{L}}, \mathrm{Mcl}-1$, or shRNA for knockdown of Bim and purified on the basis of GFP expression. Cells were then cultured in the presence or absence of tamoxifen and their survival was measured; data are presented as in $\left.A .{ }^{\star \star \star}\right) P<0.001$. (C) RNAi-mediated suppression of Mcl-1 in MLL-AF9 plus N-Ras AML cells. Graphs represent the percentages of cells coexpressing shRNA and the cDNAs indicated over time following doxycycline treatment.
Anti-apoptotic Bcl- $x_{L}, B c 1-2$, and Bcl-w are collectively dispensable for sustained in vitro survival of $A M L$

Although loss of Bcl- $\mathrm{x}_{\mathrm{L}}$ had only a minor impact, it may have a critical function in AML cell survival that overlaps with Bcl-2 and/or Mcl-1. We therefore treated MLL-ENL transformed AML cells with ABT-737, a BH3 mimetic that potently binds and inactivates Bcl- $\mathrm{x}_{\mathrm{L}}, \mathrm{Bcl}-2$, and Bcl-w (but not Mcl-1 or A1) (Oltersdorf et al. 2005), but on its own this had only a minor impact on viability (Fig. 2C). Moreover, ABT-737 further decreased the viability of $m \mathrm{cl}^{-} \mathrm{1}^{\text {fl/ }} ;{ }$ cre $/+$ AML cells that had also been treated with tamoxifen to lose one mcl-1 allele to only a limited extent (Fig. 2C). This indicates that, collectively, Bcl-2, Bcl- $\mathrm{x}_{\mathrm{L}}$, and Bcl-w have only a minor role in sustaining the survival of AML cells. 


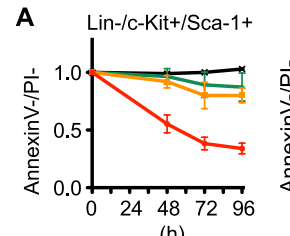

(h)

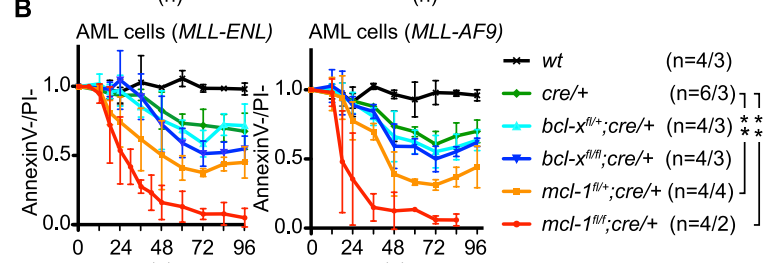

(h)

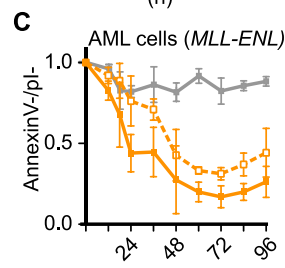

(h)

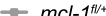

$=\mathrm{a}=\mathrm{mcl}-\mathbf{1}^{\mathrm{Tl/} ;} ; \mathrm{cre} /+(\mathrm{Tam})$

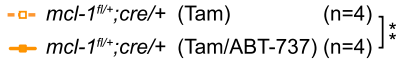

(h)

D
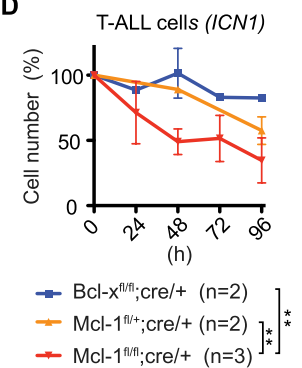

Figure 2. Impact of conditional in vitro deletion of $b c l-x$ or $m c l-1$ in normal hematopoietic stem and progenitor cells and in vivo derived AML cells. (A) Normal LSK (left panel) and $\mathrm{Lin}^{-} \mathrm{c}-\mathrm{Kit}^{+} \mathrm{Sca}-1^{-}$ myeloid progenitors (right panel) were cultured in the presence or absence of tamoxifen and cell survival was determined; data are presented as in Figure 1A. (B) Leukemic cells from mice bearing MLL-ENL-induced (left panel) or MLL-AF9-induced (right panel) AML were cultured in the presence or absence of tamoxifen and cell survival was determined; data are presented as described in Figure 1A. $\left(^{\star \star}\right) P<0.01$. (C) MLL-ENL transformed AML cells of the indicated genotypes were grown in medium containing tamoxifen, ABT-737 (1 $\mu \mathrm{M})$, or tamoxifen plus ABT-737 (1 $\mu \mathrm{M})$. Cell survival was determined, and data are presented as described in Figure 1A. $\left.{ }^{* \star}\right) P<0.01$. (D) Leukemic cells from mice bearing ICN1-induced T-ALL of the indicated genotypes were cultured in the presence or absence of tamoxifen. Cell survival was determined, and data are presented as described in Figure 1A. ${\left({ }^{\star \star}\right)}^{*}<0.01$.

Sustained survival of T-ALL is possible in the absence of $\mathrm{Mcl}-1$

To examine whether Mcl-1 is generally essential for the sustained survival and growth of all types of leukemic cells, we generated T-ALL by reconstituting lethally irradiated mice with $b c l-x^{f l / f l} ; c r e /+, m c l-1^{f l /+} ; c r e /+$, or $m c l-1^{f l / f l} ; c r e /+$ bone marrow cells that had been retrovirally transduced with an expression vector encoding intracellular NOTCH1 (ICN1), an oncogene implicated in human T-ALL (Supplemental Fig. 4A; Allman et al. 2001). Treatment of GFP ${ }^{+}$leukemic $\mathrm{T}$ cells maintained on OP9-DL1 feeder cells with tamoxifen led to efficient recombination of the $m c l-1^{f l}$ allele, as evidenced by hCD4 reporter expression (Supplemental Fig. 4B). Although loss of Mcl-1 (but not loss of Bcl- $\mathrm{x}_{\mathrm{L}}$ ) elicited some reduction in T-ALL viability in vitro, a large fraction of T-ALL cells could survive longer term in the absence of Mcl-1 (Fig. 2D). This is in striking contrast to the obliteration of AML cells caused by Mcl-1 loss (Figs. 1A,C, 2B), and thereby demonstrates that the requirement for Mcl-1 for sustained growth and survival of transformed cells is specific to certain types of leukemia.
Deletion of mcl-1 but not bcl-x kills murine AML within the whole animal

The impact of loss of Mcl-1 or Bcl- $\mathrm{x}_{\mathrm{L}}$ on AML within the whole animal was assessed by administering AMLburdened mice with tamoxifen. TUNEL staining of the marrow $3 \mathrm{~d}$ after tamoxifen treatment revealed significant (albeit moderate) apoptosis of $b c l-x^{f l / f 1} ; c r e /+$ AML cells, more abundant death of $m c l-1^{f l /+} ;$ cre $/+$ AML cells, and widespread apoptosis of $m c l-1^{f l / f l} ;$ creER/+ leukemic blasts (Fig. 3A, top panels; Supplemental Fig. 5A). Accordingly, almost no leukemic blasts were evident in histological examination $5 \mathrm{~d}$ after tamoxifen treatment of mice that had previously developed MLL-ENL transformed $\mathrm{mcl}^{-1^{f l / f l}} ; \mathrm{cre} /+$ AML (Fig. 3A, bottom panels). On the fifth day after starting treatment, we found $24 \times 10^{6}$ to $70 \times 10^{6} \mathrm{GFP}^{+}$ wild-type, cre/+, bcl- $x^{f l /+} ; c r e /+$, or $b c l-x^{f l / f 1} ;$ cre/+ cells and $26 \times 10^{6} \pm 21 \times 10^{6} \mathrm{GFP}^{+} \mathrm{mcl}^{-1^{\mathrm{fl} /+}} ; \mathrm{cre} /+\mathrm{AML}$ cells but almost no $\left(0.2 \times 10^{6} \pm 0.2 \times 10^{6}\right) \mathrm{GFP}^{+} \mathrm{mcl}^{-1}{ }^{\text {fl/fl }} ;$ cre $/+$ AML cells (Fig. 3B). All mice treated with tamoxifen $3 \mathrm{wk}$ after transplantation with MLL-ENL transduced bone marrow cells relapsed with AML. In contrast, when treated with tamoxifen at day 10 or day 5 post-transplantation, only half or none, respectively, of the $m c l-1^{f l / f l}$; cre/+ AMLburdened mice became sick during observation for $>1$ year. In contrast, their untreated counterparts survived for only $49 \pm 5 \mathrm{~d}(P<0.001)$, and untreated or tamoxifen-treated mcl-1 ${ }^{f l /+} ;$ cre/+ AML-burdened mice lived for $49 \pm 3 \mathrm{~d}$ or 66 $\pm 1 \mathrm{~d}$, respectively (Fig. 3C). These findings were confirmed by demonstrating that tetracycline-induced RNAi-mediated knockdown of Mcl-1 in vivo caused clearance of AML cells from the liver and spleen and substantially prolonged survival of such tumor-burdened mice (Supplemental Fig. 5B-D).

All relapsed $b c l-x^{f l / f 1} ; c r e /+$ and $m c l-1^{f l /+} ; c r e /+$ AML from tamoxifen-treated mice had efficiently deleted their floxed alleles, as reflected by the absence of Bcl$\mathrm{x}_{\mathrm{L}}$ protein (Fig. 3D) or by Southern blot analysis and hCD4 reporter expression (Supplemental Fig. 6A,B). In contrast, all relapsed $m c l-1^{\text {fl/f }} ;$ cre/+ AML arose from variant leukemic cells bearing mutations that debilitate CreERT2-mediated recombination. Most (eight out of nine) of these relapsed $m c l-1^{f l / f 1} ; c r e /+$ AML had not recombined both $m c 1-1^{f 1}$ alleles due to mutated CreERT2, as evidenced by the absence of hCD4 reporter (Supplemental Fig. 6B) and Cre-ERT2 protein expression (Fig. 3E). Retroviral reintroduction of CreERT2 and tamoxifen treatment allowed $m c l-1^{f l}$ recombination and consequently rapidly killed such cells in vitro (Supplemental Fig. 6C). Another $m c l-1^{f l / f 1}$; cre/+ AML (\#890) contained CreERT2 protein but had recombined only one $m c l-1$ allele due to a deletion mutation in one $\operatorname{lox} P$ site, as reflected by Western blotting (Fig. 3E), hCD4 expression, and DNA sequencing (Supplemental Fig. 6B,D). These results show that Mcl-1 is essential for sustained survival and expansion of AML within the whole animal-only AML cells that had escaped mcl-1 deletion could cause tumor relapse.

\section{Mcl-1 is critical for sustained survival of human $A M L$-derived cell lines and primary human $A M L$}

These gene deletion studies in murine AML indicated that pharmacological inhibition of Mcl-1 might be effective for treatment of this malignant disease in humans. However, small organic BH3 mimetic compounds specifically targeting Mcl-1 have yet to be developed. To test 

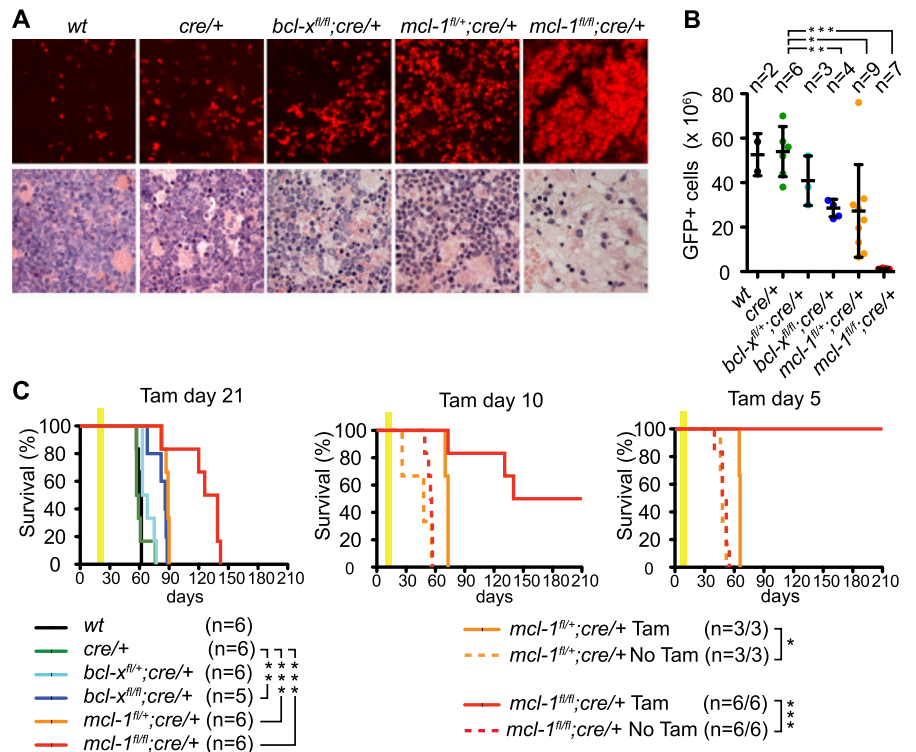

$\left.-m c l-1^{n++} ; c r e /+\operatorname{Tam} \quad(n=3 / 3)\right]$ *

- - - $m c l-1^{1 /++} ; c r e /+$ No Tam $\left.(n=3 / 3)\right]$ *

- $\left.m c l-1^{\text {thrf }} ; \mathrm{cre} /+\operatorname{Tam} \quad(\mathrm{n}=6 / 6)\right]_{\star}^{*}$

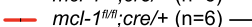

D
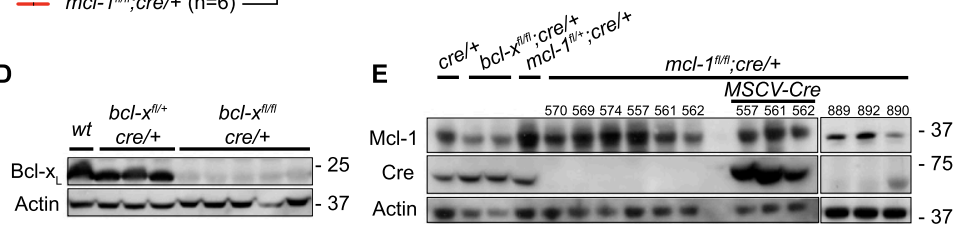

Figure 3. Conditional deletion of mcl-1 causes regression of AML in tumorburdened mice. (A) Histological examination of bone marrow from mice burdened with MLL-ENL-induced AML of the indicated genotypes. The top panels show apoptosis of cells (detected by TUNEL staining) after $3 \mathrm{~d}$ of treatment with tamoxifen. The bottom panels show the presence of leukemic blasts after $5 \mathrm{~d}$ of treatment with tamoxifen. (B) Symptomatic (elevated leukocyte counts, thrombocytopenia, and anemia) mice bearing MLL-ENLinduced AML of the indicated genotypes were treated for $5 \mathrm{~d}$ with tamoxifen. Shown are the total numbers of GFP leukemic cells collected from two femora and two tibiae on the sixth day. $\left(^{\star}\right) P<0.05$; $\left.^{(\star *}\right) P<0.01$; $\left(^{\star \star \star}\right) P<0.001 .(C)$ Survival of AML-burdened mice that were treated with tamoxifen (treatment window indicated by yellow bar) $21 \mathrm{~d}$ (left panel) $10 \mathrm{~d}$ (middle panel) or $5 \mathrm{~d}$ (right panel) after transplantation with MLL-ENL transformed AML cells of the indicated genotypes. Untreated mice (dotted lines) from the same cohort treated with tamoxifen at $10 \mathrm{~d}$ or $5 \mathrm{~d}$ all developed disease, thus confirming the presence of AML at that time pointl $\left({ }^{\star}\right) P<0.05$; $\left.\left.\right|^{\star \star}\right) P<0.01$; $\left(^{\star \star \star}\right) P<0.001 .(D, E)$ Western blot analysis to detect Bcl- $\mathrm{x}_{\mathrm{L}}(D)$ or Mcl-1 and CreER proteins $(E)$ in leukemic cells of the indicated genotypes from mice that relapsed with AML after tamoxifen treatment.

the impact of functional inactivation of Mcl-1 in human AML, we employed lentiviral expression of Bim S-derived $^{-}$ $\mathrm{BH} 3$ variant ligands: $\mathrm{Bim}_{\mathrm{S}} 4 \mathrm{E}$, an inert Bim variant (negative control) (Chen et al. 2005); Bim 2 A to target Mcl-1 but not Bcl-2, Bcl- $\mathrm{x}_{\mathrm{L}}, \mathrm{Bcl}-\mathrm{w}$, or A1 (Lee et al. 2008); $\mathrm{Bim}_{\mathrm{S}} \mathrm{Bad}$ to target $\mathrm{Bcl}-2, \mathrm{Bcl}-\mathrm{x}_{\mathrm{L}}$, and Bcl-w but not Mcl-1 or A1 (Merino et al. 2009); and Bim $\mathrm{S}$ wt to target all prosurvival Bcl-2 proteins (Chen et al. 2005) (Supplemental Fig. 7A). Doxycycline-induced expression of RFP or Bim $_{S} 4 \mathrm{E}$ for $72 \mathrm{~h}$ in MLL-ENL transformed mouse AML or multiple human AML- and chronic myeloid leukemia (CML)-derived cell lines did not reduce the numbers of lentivirally transduced $\left(\mathrm{GFP}^{+}\right)$cells compared with uninduced cultures (Fig. 4A; Supplemental Fig. 7B). In contrast, Bim $_{\mathrm{S}} \mathrm{wt}$ expression greatly reduced the viability of all tested cell lines (Fig. 4A; Supplemental Fig. 7B). Importantly, blockade of Mcl-1 by Bim ${ }_{S} 2 \mathrm{~A}$ potently killed six of seven AML-derived cell lines but had only minor impact on the human erythroleukemia-derived (HEL92.1.7) and CML-derived (KU-812 and K562) cell lines (Fig. 4A). Interestingly, the few $\mathrm{GFP}^{+} \mathrm{MV} 4,11$ cells that remained viable after $3 \mathrm{~d}$ of doxycycline treatment exhibited low or no Bims $2 \mathrm{~A}$ expression (Supplemental Fig. 7C), indicating that selection against Mcl-1 blockade had occurred. In contrast, Bim ${ }_{S} B a d$ expression (Fig. 4A) or ABT-737 treatment (Fig. 4B), both of which block Bcl-2, Bcl- $\mathrm{x}_{\mathrm{L}}$, and Bcl-w (Oltersdorf et al. 2005; Merino et al. 2009), did not reduce the viability of most AML lines, except the ML-1, HL-60, and MV4,11 cells (small but significant effect), but they potently killed the human erythroleukemia (HEL92.1.7) and CML (KU-812) cell lines. Bim 2 A-mediated Mcl-1 blockade in combination with ABT-737 treatment for $40 \mathrm{~h}$ led to almost complete killing of all cell lines tested (Fig. 4B), consistent with the notion that cells cannot survive when a broad range of prosurvival Bcl-2 proteins are inactivated.

We next transduced primary AML cells from patients (Supplemental Fig. 7D) with the aforementioned expression constructs to block Mcl-1 $\left(\mathrm{Bim}_{\mathrm{s}} 2 \mathrm{~A}\right)$ or all prosurvival $\mathrm{Bcl}-2$ proteins $\left(\mathrm{Bim}_{\mathrm{s}} \mathrm{wt}\right)$, using $\operatorname{Bim}_{\mathrm{s}} 4 \mathrm{E}$ as a negative control. Interestingly, two primary human AMLs (\#1 and \#3) showed substantially reduced viability after doxycyclinemediated induction of $\operatorname{Bim}_{\mathrm{S}} 2 \mathrm{~A}$ or Bim $\mathrm{S}$ wt but not after induction of (inactive) Bim 4 $4 \mathrm{E}$ (Fig. 4C). Some primary human AML, however, did not show a significant drop in viability after doxycycline treatment. Although in some AML cells this may have been due to insufficient induction of $\operatorname{Bim}_{\mathrm{s}} 2 \mathrm{~A}$ or $\mathrm{Bim}_{\mathrm{s}} \mathrm{wt}$, we remarkably found mutated Bak (abnormal protein size) and abnormally low Bax levels in AML \#2 and very low expression levels of both Bax and Bak in AML \#5 (Fig. 4C). It appears likely that the therapeutic treatments that these patients received prior to our analysis selected for outgrowth of AML with such generalized defects in the "Bcl-2-regulated" apoptotic pathway.

Collectively, these results demonstrate that Mcl-1 is critical for the sustained survival and expansion of mouse as well as human AML resulting from a broad range of oncogenic lesions, whereas $\mathrm{Bcl}-\mathrm{x}_{\mathrm{L}}$ Bcl-w, or Bcl-2, as reported (Zuber et al. 2011b), play minor prosurvival roles in these cancers. As such, these findings encourage the development of pharmacologic inhibitors that target Mcl-1 or regulators of its expression for treatment of this hematological malignancy.

\section{Materials and methods}

\section{Animals}

Experiments with mice were conducted according to the guidelines of The Walter and Eliza Hall Institute Animal Ethics Committee. $b c l-x^{f l / f l}$ (Wagner et al. 2000), ccl- $^{f^{f l / f 1}}$ (Supplemental Fig. 1A; Vikstrom et al. 2010) and the Rosa26-CreERT2 (Seibler et al. 2003) (Taconic Artemis) gene targeted mice (all on a C57BL/6 background) have been described. Mice received one aliquot containing $4 \mathrm{mg}$ of tamoxifen (Sigma, T5648) per day for five consecutive days by oral gavage as described previously (Anastassiadis et al. 2010).

\section{Generation and culture of transformed leukemic cells}

MLL-ENL and MLL-AF9 retroviral constructs were obtained from Drs. R. Slany and M. Cleary, the AML1-ETO9a retroviral construct was obtained from Dr. D.-E. Zhang (Addgene plasmid 12433) (Yan et al. 2006), the Hoxa9 
Glaser et al.

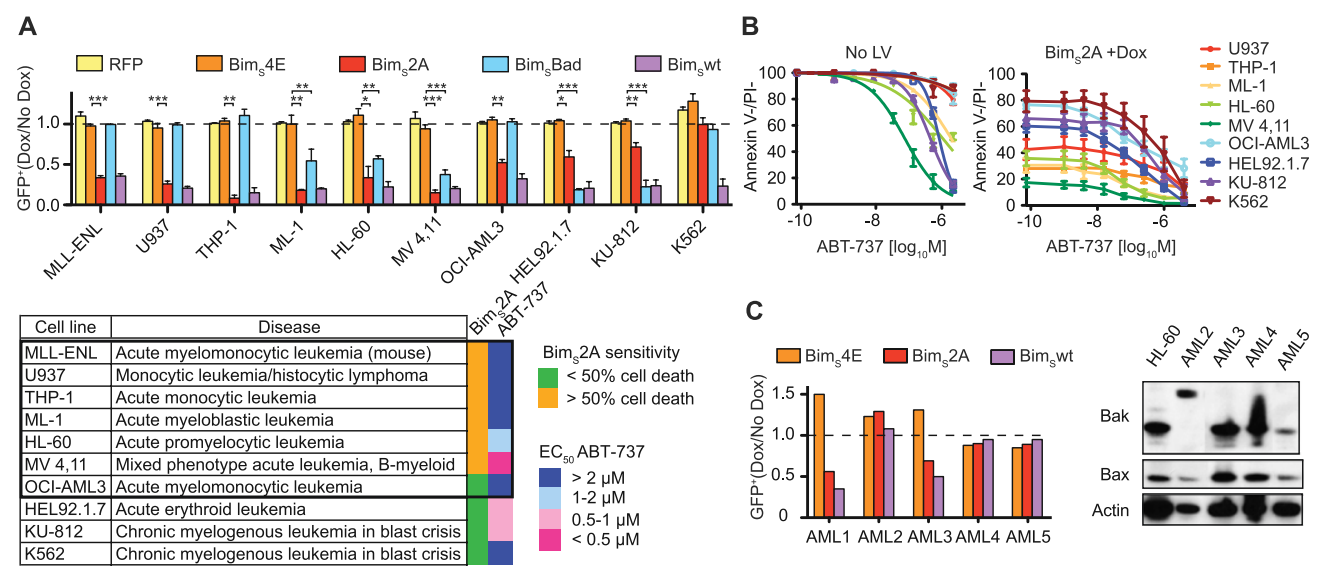

Figure 4. Impact of functional inactivation of Mcl-1 by inducible expression of Bim-derived BH3-like ligands that selectively neutralize different prosurvival Bcl-2 family members in human leukemia-derived cell lines and primary human AML cells. (A) Mouse AML cells and human leukemia-derived cell lines (U937, THP-1, ML-1, HL-60, MV4,11, OCI-AML3, HEL92.1.7, KU-812, and K562) were transduced with lentiviral constructs that allow inducible expression of Bim $\mathrm{S}_{\mathrm{S}} \mathrm{E}$ (negative control, no binding to Bcl-2-like proteins), Bim $\mathrm{S} 2 \mathrm{~A}$ (binding only Mcl-1), Bim $\mathrm{S}$ Bad (binding Bcl-2, Bcl- $\mathrm{x}_{\mathrm{L}}$ and Bcl-w but not Mcl-1 or A1), or Bimswt (binding all Bcl-2 prosurvival proteins) and were either left untreated or treated with doxycycline. Graphs represent the ratio of $\mathrm{GFP}^{+}$cells (doxycycline-treated compared with untreated) detected by flow cytometry of at least three experiments for each cell line. In the table, cell lines derived from AML are boxed; the heat map summarizes the sensitivity of all cell lines to Bims 2 A expression or ABT-737 treatment. (B) The cell lines indicated were treated with the indicated doses of ABT-737 alone (left panel) or in combination with induced Bim 2 2A (inhibits Mcl-1) expression (right panel). (C) Primary human AML cells were transduced with Bim $\mathrm{S} 4 \mathrm{E}-\mathrm{encoding}$ (negative control), Bim $\mathrm{S} 2 \mathrm{~A}$-encoding (inhibits Mcl-1), or Bim $\mathrm{S}$ wt-encoding (inhibits all prosurvival Bcl-2 family members) lentiviruses and were either left untreated or treated with doxycycline. Shown is a graph representing the ratio of doxycycline-treated compared with untreated GFP ${ }^{+}$ AML blast cells from one representative experiment for each patient sample. Western blot analysis to detect Bax and Bak protein levels in primary AML cells. Low levels of Bax and Bak were detected in sample \#5; low levels of Bax and abnormal size of Bak were detected in sample \#2.

retroviral construct was obtained from Dr. C. Largman (Addgene plasmid 8515) (Shen et al. 1997), and the Mixll retroviral construct was described previously (Glaser et al. 2006). The Bcl-2, Bcl- $\mathrm{x}_{\mathrm{L}}$, and Mcl-1 retroviral expression constructs were provided by Dr. D.C.S. Huang. The CreERhCD2 retroviral construct was provided by Dr. M. Bussliner (IMP, Vienna, Austria), and the retroviral construct for shRNA-mediated knockdown of Bim has been described (Bouillet et al. 2005). Lentiviral expression constructs were generated by KpnI digestion, and by cloning a synthesized 1638-base-pair (bp) fragment containing GFP-WPRE and AgeI/ClaI digestion and cloning of $\mathrm{Bim}_{\mathrm{S}}$ variants into the TRIPZ vector (Open Biosystems). Viral supernatants were produced by $\mathrm{CaCl}_{2}$ cotransfection of $293 \mathrm{~T}$ cells with expression constructs and packaging plasmids. Fetal liver (E13.5 [embryonic day 13.5] embryos) or bone marrow cells from 5-FU-treated mice were enriched for immature cells by immunomagnetic depletion of mature lymphoid $\left(\mathrm{CD}^{+}, \mathrm{CD}^{+}, \mathrm{CD} 8^{+}\right.$, and $\left.\mathrm{B}_{2} 20^{+}\right)$ myeloid $\left(\mathrm{Macl}^{+}\right.$and $\left.\mathrm{Grl}^{+}\right)$and erythroid $\left(\mathrm{Ter} 119^{+}\right)$cells. Viral transduction was performed as described (Metcalf et al. 2007). Transduced cells were cultured in Dulbecco's modified Eagle's medium supplemented with $20 \%$ FBS (HyClone), $2 \mathrm{mM}$ L-glutamine, $100 \mathrm{ng} / \mathrm{mL}$ murine stem cell factor, and $10 \mathrm{ng} / \mathrm{mL}$ IL-3 (Peprotech). Infected cells were either FACS-sorted on the basis of GFP expression for in vitro studies or injected unsorted into sublethally $\gamma$-irradiated (5.5 Gy) C57BL/6 mice. Cells retrovirally transduced with the MLL-ENL/neo expression vector were plated in methylcellulose medium M3234 (Stem Cell Technologies) supplemented with $100 \mathrm{ng} / \mathrm{mL}$ murine stem cell factor, $10 \mathrm{ng} / \mathrm{mL} \mathrm{IL-3,} \mathrm{and}$ $1 \mathrm{mg} / \mathrm{mL}$ G418 (InvivoGen). G418-resistant cells from the third plating were transduced with retroviral constructs encoding Bcl-2 family members or RNA hairpins for knockdown of Bim and were linked with IRES-GFP, and transduced cells were subsequently isolated by cell sorting. Cremediated recombination in vitro was induced by treatment with $10^{-7} \mathrm{M}$ 4-hydroxy tamoxifen (Sigma, H7904) (Glaser et al. 2009). For analysis of protein levels by Western blotting, $m c l-1^{f l / f l} ; \mathrm{creER} /+$ cells were treated with tamoxifen in the presence of the pan-caspase inhibitor qVD-OPh $(25 \mu \mathrm{M}$; MP Biomedicals) to protect them from apoptotic death.

Detailed methodology is described in the Supplemental Material.

\section{Acknowledgments}

We thank Drs. L. Hennighausen, J.M. Adams, S. Cory, D.C.S. Huang, M. Cleary, D.-E. Zhang, C. Largman, and M. Busslinger for gifts of mice and retroviral constructs. This work was supported by grants and fellowships from the Deutsche Forschungsgemeinschaft (DFG) (to S.G.), the Lady Tata Memorial Trust (to S.G.), the NHMRC (programs 257500 and 461221; projects 637326 and 1008329; fellowships 356203, 461299, and 575501; and Independent Research Institutes Infrastructure Support Scheme grant 361646), the Leukemia and Lymphoma Society (SCOR grant 7413), the NIH (CA43540 and CA80188), the Victorian Cancer Agency, the Leukemia Foundation of Australia, and the Australian Cancer Research Fund, and by operational infrastructure grants through the Australian Government (IRISS) and the Victorian State Government (OIS).

\section{References}

Allman D, Karnell FG, Punt JA, Bakkour S, Xu L, Myung P, Koretzky GA, Pui JC, Aster JC, Pear WS. 2001. Separation of Notch1 promoted lineage commitment and expansion/transformation in developing $\mathrm{T}$ cells. J Exp Med 194: 99-106.

Anastassiadis K, Glaser S, Kranz A, Berhardt K, Stewart AF. 2010. A practical summary of site-specific recombination, conditional mutagenesis, and tamoxifen induction of CreERT2. Methods Enzymol 477: 109-123.

Ayton PM, Chen EH, Cleary ML. 2004. Binding to nonmethylated CpG DNA is essential for target recognition, transactivation, and myeloid transformation by an MLL oncoprotein. Mol Cell Biol 24: 1047010478.

Beroukhim R, Mermel C, Porter D, Wei G, Raychaudhuri S, Donovan J, Barretina J, Boehm J, Dobson J, Urashima M, et al. 2010. The landscape of somatic copy-number alteration across human cancers. Nature 463: 899-905.

Bouillet P, Robati M, Bath ML, Strasser A. 2005. Polycystic kidney disease prevented by transgenic RNA interference. Cell Death Differ 12: 831-833.

Chen L, Willis SN, Wei A, Smith BJ, Fletcher JI, Hinds MG, Colman PM, Day CL, Adams JM, Huang DCS. 2005. Differential targeting of prosurvival Bcl-2 proteins by their BH3-only ligands allows complementary apoptotic function. Mol Cell 17: 393-403.

Estey E, Dohner H. 2006. Acute myeloid leukaemia. Lancet 368: 18941907. 
Glaser S, Metcalf D, Wu L, Hart AH, DiRago L, Mifsud S, D'Amico A, Dagger S, Campo C, Chan AC, et al. 2006. Enforced expression of the homeobox gene Mixll impairs hematopoietic differentiation and results in acute myeloid leukemia. Proc Natl Acad Sci 103: 1646016465.

Glaser S, Lubitz S, Loveland KL, Ohbo K, Robb L, Schwenk F, Seibler J, Roellig D, Kranz A, Anastassiadis K, et al. 2009. The histone 3 lysine 4 methyltransferase, Mll2, is only required briefly in development and spermatogenesis. Epigenetics Chromatin 2: 5. doi: 10.1186/17568935-2-5.

Jiao B, Wu CF, Liang Y, Chen HM, Xiong SM, Chen B, Shi JY, Wang YY, Wang JH, Chen Y, et al. 2009. AML1-ETO9a is correlated with C-KIT overexpression/mutations and indicates poor disease outcome in $\mathrm{t}(8 ; 21)$ acute myeloid leukemia-M2. Leukemia 23: 1598-1604.

Johnstone RW, Ruefli AA, Lowe SW. 2002. Apoptosis: A link between cancer genetics and chemotherapy. Cell 108: 153-164.

Kaufmann SH, Karp JE, Svingen PA, Krajewski S, Burke PJ, Gore SD, Reed JC. 1998. Elevated expression of the apoptotic regulator Mcl-1 at the time of leukemic relapse. Blood 91: 991-1000.

Lavau C, Luo RT, Du C, Thirman MJ. 2000. Retrovirus-mediated gene transfer of MLL-ELL transforms primary myeloid progenitors and causes acute myeloid leukemias in mice. Proc Natl Acad Sci 97: 10984-10989.

Lee EF, Czabotar PE, van Delft MF, Michalak E, Boyle M, Willis SN, Puthalakath H, Bouillet P, Colman PM, Huang DCS, et al. 2008 . A novel BH3 ligand that selectively targets Mcl-1 reveals that apoptosis can proceed without Mcl-1 degradation. I Cell Biol 180: 341-355.

Merino D, Giam M, Hughes PD, Siggs OM, Heger K, O'Reilly LA, Adams JM, Strasser A, Lee EF, Fairlie WD, et al. 2009. The role of BH3-only protein Bim extends beyond inhibiting Bcl-2-like prosurvival proteins. J Cell Biol 186: 355-362.

Metcalf D, Glaser S, Mifsud S, Di Rago L, Robb L. 2007. The preleukemic state of mice reconstituted with Mixll-transduced marrow cells. Proc Natl Acad Sci 104: 20013-20018.

Oltersdorf T, Elmore SW, Shoemaker AR, Armstrong RC, Augeri DJ, Belli BA, Bruncko M, Deckwerth TL, Dinges J, Hajduk PJ, et al. 2005. An inhibitor of Bcl-2 family proteins induces regression of solid tumours. Nature 435: 677-681.

Opferman J, Iwasaki H, Ong CC, Suh H, Mizuno S, Akashi K, Korsmeyer SJ. 2005. Obligate role of anti-apoptotic MCL-1 in the survival of hematopoietic stem cells. Science 307: 1101-1104.

Schwickart M, Huang X, Lill JR, Liu J, Ferrando R, French DM, Maecker H, O'Rourke K, Bazan F, Eastham-Anderson J, et al. 2010. Deubiquitinase USP9X stabilizes MCL1 and promotes tumour cell survival. Nature 463: 103-107.

Seibler J, Zevnik B, Kuter-Luks B, Andreas S, Kern H, Hennek T, Rode A, Heimann C, Faust N, Kauselmann G, et al. 2003. Rapid generation of inducible mouse mutants. Nucleic Acids Res 31: e12. doi: 10.1093/ nar/gng012.

Shen WF, Montgomery JC, Rozenfeld S, Moskow JJ, Lawrence HJ, Buchberg AM, Largman C. 1997. AbdB-like Hox proteins stabilize DNA binding by the Meis1 homeodomain proteins. Mol Cell Biol 17: 6448-6458.

Somervaille TC, Cleary ML. 2006. Identification and characterization of leukemia stem cells in murine MLL-AF9 acute myeloid leukemia. Cancer Cell 10: 257-268.

Thorsteinsdottir U, Mamo A, Kroon E, Jerome L, Bijl J, Lawrence HJ, Humphries K, Sauvageau G. 2002. Overexpression of the myeloid leukemia-associated Hoxa9 gene in bone marrow cells induces stem cell expansion. Blood 99: 121-129.

Vikstrom I, Carotta S, Luethje K, Peperzak V, Jost PJ, Glaser S, Busslinger M, Bouillet P, Strasser A, Nutt SL, et al. 2010. Mcl-1 is essential for germinal center formation and B cell memory. Science 330: 10951099

Wagner KU, Claudio E, Rucker EB 3rd, Riedlinger G, Broussard C, Schwartzberg PL, Siebenlist U, Hennighausen L. 2000. Conditional deletion of the Bcl-x gene from erythroid cells results in hemolytic anemia and profound splenomegaly. Development 127: 4949-4958.

Yan M, Kanbe E, Peterson LF, Boyapati A, Miao Y, Wang Y, Chen IM, Chen Z, Rowley JD, Willman CL, et al. 2006. A previously unidentified alternatively spliced isoform of $\mathrm{t}(8 ; 21)$ transcript promotes leukemogenesis. Nat Med 12: 945-949.
Youle RJ, Strasser A. 2008. The BCL-2 protein family: Opposing activities that mediate cell death. Nat Rev Mol Cell Biol 9: 47-59.

Zuber J, Radtke I, Pardee TS, Zhao Z, Rappaport AR, Luo W, McCurrach ME, Yang MM, Dolan ME, Kogan SC, et al. 2009. Mouse models of human AML accurately predict chemotherapy response. Genes Dev 23: $877-889$.

Zuber J, McJunkin K, Fellmann C, Dow LE, Taylor MJ, Hannon GJ, Lowe SW. 2011a. Toolkit for evaluating genes required for proliferation and survival using tetracycline-regulated RNAi. Nat Biotechnol 29: 7983.

Zuber J, Rappaport AR, Luo W, Wang E, Chen C, Vaseva AV, Shi J, Weissmueller S, Fellmann C, Taylor MJ, et al. 2011b. An integrated approach to dissecting oncogene addiction implicates a Myb-coordinated self-renewal program as essential for leukemia maintenance. Genes Dev 25: 1628-1640. 


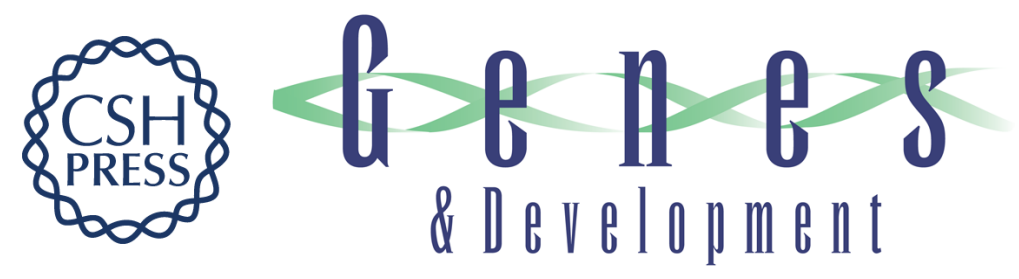

\section{Anti-apoptotic Mcl-1 is essential for the development and sustained growth of acute myeloid leukemia}

Stefan P. Glaser, Erinna F. Lee, Evelyn Trounson, et al.

Genes Dev. 2012, 26:

Access the most recent version at doi:10.1101/gad.182980.111

\section{Supplemental http://genesdev.cshlp.org/content/suppl/2012/01/25/26.2.120.DC1 \\ Material}

Related Content Selectively targeting Mcl-1 for the treatment of acute myelogenous leukemia and solid tumors

Gregory J. Gores and Scott H. Kaufmann

Genes Dev. February , 2012 26: 305-311

References This article cites 30 articles, 15 of which can be accessed free at: http://genesdev.cshlp.org/content/26/2/120.full.html\#ref-list-1

Articles cited in:

http://genesdev.cshlp.org/content/26/2/120.full.html\#related-urls

\section{License}

Email Alerting

Service

Receive free email alerts when new articles cite this article - sign up in the box at the top right corner of the article or click here.

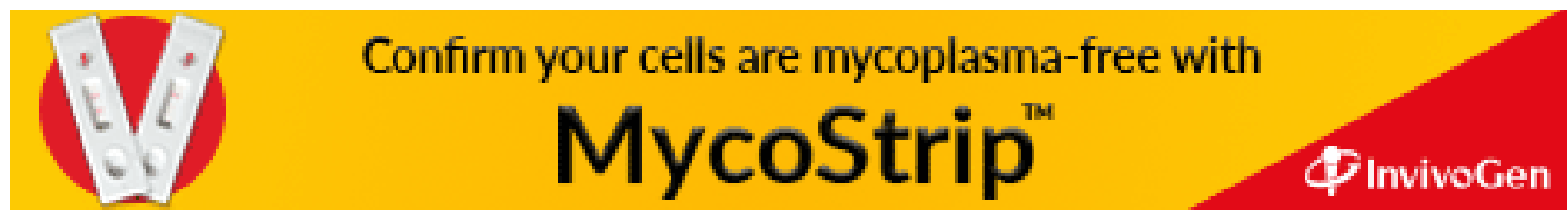

